\title{
Determine the Optimal Density of Nile Tilapia (Oreochromis niloticus) Fingerlings Cultured in Floating Cages
}

\author{
B. A. El Nouman, O. A. Egbal*, Y. A. Sana, M. S. Anwar, A. A. Eman, F. A. Yosif \\ School of Fish Science, Al Neelain University, Khartoum, Sudan \\ Email: *egbalosman1@gmail.com
}

How to cite this paper: El Nouman, B.A., Egbal, O.A., Sana, Y.A., Anwar, M.S., Eman, A.A. and Yosif, F.A. (2021) Determine the Optimal Density of Nile Tilapia (Oreochromis niloticus) Fingerlings Cultured in Floating Cages. Natural Resources, 12, 1-9. https://doi.org/10.4236/nr.2021.121001

Received: November 25, 2020

Accepted: January 24, 2021

Published: January 27, 2021

Copyright (c) 2021 by author(s) and Scientific Research Publishing Inc. This work is licensed under the Creative Commons Attribution International License (CC BY 4.0).

http://creativecommons.org/licenses/by/4.0/

(c) (i) Open Access

\begin{abstract}
The objective of the study was to determine the optimal density of fingerlings of the Nile tilapia (Oreochromis niloticus) culture in floating cages with respect to growth performance and to know the effect of temperature on growth during the winter period. Tilapia fingerlings (mean weight $8.5 \pm$ $0.36 \mathrm{~g}$ ) were stocked at densities of 120,180 and $360 \mathrm{fish} / \mathrm{m}^{3}$ for 10 weeks. During culture, fish were fed a diet contains 35\% protein made of peanut seed, cottonseed, wheat bran, and Sorghum. The results showed that the increase in fish density reduced the final weight of the fish. The percentage of the fish weight increased and reached $111 \% \pm 1.45 \%$ in the lowest fish density $\left(120 \mathrm{fish} / \mathrm{m}^{3}\right), 79 \% \pm 1.87 \%$ in the medium density $\left(240 \mathrm{fish} / \mathrm{m}^{3}\right)$, and $63 \% \pm 2.03 \%$ of high fish density $\left(360 \mathrm{fish} / \mathrm{m}^{3}\right)$, therefore the daily growth rate was better in the lowest density. The rate of food conversion ratio was also better in the lowest density with $2.17 \pm 0.33$, followed by the medium density with $2.79 \pm 0.28$ and then the highest density with $3.09 \pm 0.21$. However, the total production in the cage increased with increasing fish density, and the return to the cost of food was better with higher fish density. According to various performance evaluation criteria, it can be concluded that the medium density $240 \mathrm{fish} / \mathrm{m}^{3}$ is the best for growing Nile tilapia fingerlings in floating cages. It was observed that the growth rates of the three treatments were low due to the decrease in water temperature in most of the study period, which may indicate the useless of culture in cages in the winter season.
\end{abstract}

\section{Keywords}

Cage Culture, Stocking Density, Nile Tilapia Fingerlings, Growth Performance, Sudan 


\section{Introduction}

Culture of freshwater fishes in square or round boxes along with artificial feeding, management for the more production is called cage culture. This practice is suitable for the backwater because the water is present throughout the year, as this water is reserved for drinking and irrigation purposes [1]. Cage aquaculture has some advantages over other aquaculture systems that are potentially important for absorption by poor and landless rural inhabitants [2].

Tilapia is one of the most important species in a global aquaculture and widely farmed fish in the world [3]. [4] reported that Tilapia farming is booming around the world in both developed and developing countries as this group of fish can be cultured under very basic conditions and is therefore ideal for subsistence farming, but is prone to more sophisticated, market-oriented cultural programs. Tilapia is an important species throughout global, but knowledge of its appropriate stock density which can immensely affect production and efficiency of tilapia has been inadequate [5].

Fish pond density describes the number of fish that are initially stocked per unit area. It is one of the most important factors determining the production of a fish farm [6]. Stocking density is one of the keys to success in aquaculture management as it directly affects survival, growth, behavior, health, water quality, feed consumption and production. The choice of stocking densities of fish depends in part on economic factors and market demands. Therefore, studying the ideal stocking density is one of the main factors in increasing production [7]. Several studies have been carried out on the growth efficiency of fish at different densities, most results show reduced final weight when stocking density increased [7] [8] [9] [10] [11].

Fish farming in floating cages on a commercial scale has not yet been known in Sudan, despite the constituents that it enjoys in this field of lakes, rivers and irrigation canals that have not been utilized yet for this purpose. Fish culture in Sudan is therefore still in its infancy, although there is a long history of aquaculture in it, the lack of trained personnel and inadequate planning has been major impediments to its development [12].

Local research in this area is limited and information is completely lacking. Therefore, this research aims to determine the optimal density and evaluate the different densities of tilapia fingerlings in netting cages and their impact on growth efficiency, to also learn about the influence of temperature on growth in winter.

\section{Materials and Methods}

\subsection{Study Area}

The experiment was carried out in the Jabal Awlia reservoir in floating cages for 10 weeks. The Jebel Awlia Dam located $32^{\circ} 27^{\prime} \mathrm{E}$ and $15^{\circ} 12^{\prime} \mathrm{N} 45 \mathrm{~km}$ south the Khartoum capital of Sudan (Figure 1). It is only dam across the White Nile 

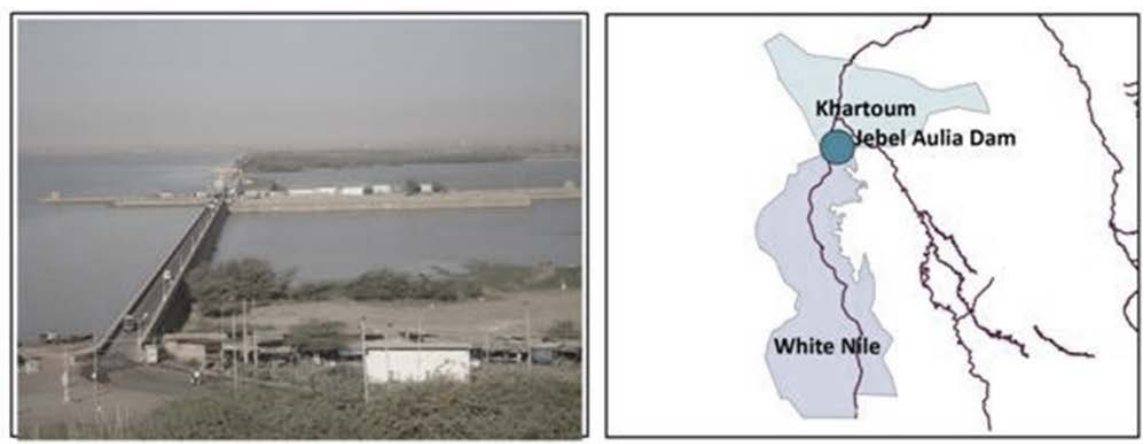

Figure 1. Jebel Awlia Dam location.

River and the largest reservoir in Sudan. The dam was completed in 1937 to provide river flows for Egypt during summer flows. It has a significant value for irrigating several agriculture schemes along its sides.

\subsection{Fabrication of Cages}

The cage frame was constructed with a dimension of $1 \mathrm{~m}(\mathrm{~L}) \times 1 \mathrm{~m}(\mathrm{~B}) \times 0.50 \mathrm{~m}$ (H) from PVC material (frame), having a volume of $1.5 \mathrm{~m}^{3}$. The cage bag was fabricated by using nylon netting material thread No. 21 with $14 \mathrm{~mm}$ mesh size. The frame was surrounded by nets from the sides completely enclosed as well as the surface and bottom of the cage. The small mesh size was selected for easy circulation of water and to avoiding the escape of fingerlings from the cages. For the artificial feeding and management of fishes, a feeding ring was prepared on the top of cages. The cage was linked from the bottom by the rope from the four corners and was assembled at a central point below the cage and then linked to the flank to install the cage to prevent the movement of the cages due to the wind and waves.

\subsection{Stocking of Fish}

Oreochromis niloticus fingerlings of (body weight $8.5 \pm 0.36 \mathrm{~g}$ ) collected from the fish farm of the faculty of Agricultural Technology and Fish Sciences, El-Neelain University. Fingerlings were adapting in the hatching ponds for food and the reservoir water. Then the fishes were carried out and transported to the floating cages, with three stocking density treatments, low density (D1) 120 fish $/ \mathrm{m}^{3}$, medium one (D2) $240 \mathrm{fish} / \mathrm{m}^{3}$ and high density (D3) $360 \mathrm{fish} / \mathrm{m}^{3}$, three replications in each treatment.

\subsection{Feeds and Feeding}

A diet was formulated from different sources of plant proteins, peanut meal, cottonseed, and wheat bran and sorghum Table 1. A diet was so formulated that it contained the same protein level of $35 \%$. All ingredient feedstuffs were first ground to fine powders in a commercial grain grinding mill, and then were prepared by thoroughly mixing the appropriate amounts of the ingredients. Water 
was then slowly added until a moist mash (dough) was obtained. The moist mash was then pelleted using an electric household meat grinder. A diet was then allowed to dry; the dry pellets were then broken into smaller crumbles to be easily consumed by the fingerlings. The results of the chemical analysis of the feed used show in Table 2.

The fish were fed 3\% of their weight daily at the start of the experiment for 6 days and the ratio was changed during the experiment according to the water temperature. Fish were fed per day with twice the first dose was given in the morning and the second dose in the middle of the day.

\subsection{Growth Performance Analysis}

The growth performance of the fish was assessed on the basis of weight gain, percentage weight gain, daily weight gain, food conversion rate, survival rate and using the formula below according to [13]

$$
\begin{gathered}
\text { Weight gain }(\mathrm{g})=\text { Final weight }(\mathrm{g})-\text { Initial weight }(\mathrm{g}) \\
\text { Weight gain }(\%)=\frac{\text { Weight gain }(\mathrm{g}) \times 100}{\text { Initial weight }(\mathrm{g})} \\
\text { Daily growth rate }(\mathrm{g} / \text { day })=\frac{\text { Final weight }- \text { Initial weight }}{\text { Number of experimental days }} \\
\text { Food Conversion Ratio }(\text { FCR })=\frac{\text { Food intake }(\mathrm{g})}{\text { Weight gain }(\mathrm{g})} \\
\text { Survival rate }(\%)=\frac{\text { Number of fish at harvest } \times 100}{\text { Number of fish stocked }}
\end{gathered}
$$

Table 1. Composition of the diet (\%).

\begin{tabular}{cc}
\hline Diets ingredients & Percentage in the diet (\%) \\
\hline Wheat bran & 11.85 \\
Peanut & 69.20 \\
Cottonseed & 15 \\
Sorghum & 3.59 \\
Total & 100 \\
\hline
\end{tabular}

Table 2. The chemical composition of feed ingredients (\%).

\begin{tabular}{cccccc}
\hline Ingredient & Dry matter & Protein & Fat & Ash & Carbohydrate \\
\hline Wheat bran & 92.3 & 11.8 & 2.5 & 3.9 & 74.1 \\
Peanut & 94.3 & 42.0 & 8.0 & 6.2 & 38.1 \\
Cottonseed & 93.2 & 26.2 & 8.1 & 4.8 & 54.1 \\
Sorghum & 91.7 & 10.7 & 3.4 & 5.1 & 72.5 \\
\hline
\end{tabular}




\subsection{Statistical Analysis}

The obtained data were analyzed by computer using the Statistical Package for Social Science (SPSS) software (version 21), means were tested for significance using mean distribution, and significance was determined at $\mathrm{P}<0.05$.

\section{Results and Discussion}

Stocking density is one of the external factors that determine the growth efficiency of farmed fish. The results from this study showed that the percent weight gain and daily weight gain were significantly changed with respect to stocking density $(\mathrm{P}<0.05)$ Table 3 . The stocking density of $120 \mathrm{fish} / \mathrm{m}^{3}$ achieved greater weight gain (\%) and daily weight gain, groups reared at high stocking levels (360 $\mathrm{fish} / \mathrm{m}^{3}$ ) showed less growth, consistent with the results obtained by [14]. Hence, assuming growth efficiency alone, the resulting trend was that as stocking density increased, final weight gain decreased Figure $2 \&$ Figure 3 . Therefore, the growth efficiency attributed to the stocking density showed an advantage of the order of $120 \mathrm{fish} / \mathrm{m}^{3}>240 \mathrm{fish} / \mathrm{m}^{3}>360 \mathrm{fish} / \mathrm{m}^{3}$ Table 3 . In the study, the decrease growth rates can be explained by the increase in fish density, that overcrowding leads to the creation of a local water environment in the cage, with a low oxygen concentration and high ammonia level. Furthermore, [15] noted that although some species of fish tolerate extreme crowding, competition for food restricts their growth, resulting in poor weight gain. The results of this study are in agreement with [15] [16] [17] who reported that an increase in stocking density had a significant impact on growth.

There were no significant differences between the three stocking densities in terms of survival rates, as the survival rate was $62 \% \pm 0.81 \%$ for $120 \mathrm{fish} / \mathrm{m}^{3}, 360$ fish $/ \mathrm{m}^{3}$ and $68 \% \pm 0.84 \%$ for $240 \mathrm{fish} / \mathrm{m}^{3}$ Table 3 . This indicates that the density of the fish did not play a role in their death. Moreover [18] and [19] noticed that high stocking densities in fish farming may sometimes have no effect on mortality rates and consequently increase fish yield. The obtained low survival rates in the present study could be attributed to unfavorable environmental conditions during the entire period of the experiment, the surface temperature of the lake water below $20^{\circ} \mathrm{C}$.

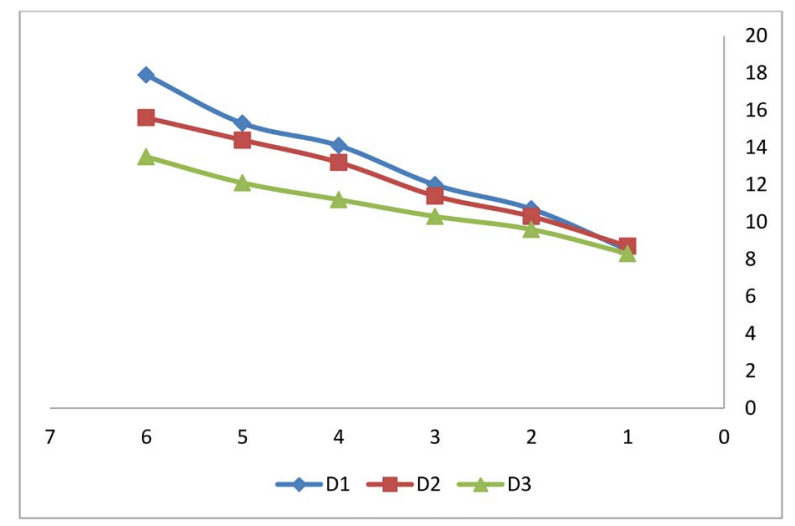

Figure 2. Growth rate (g) of fish at three stocking densities. 


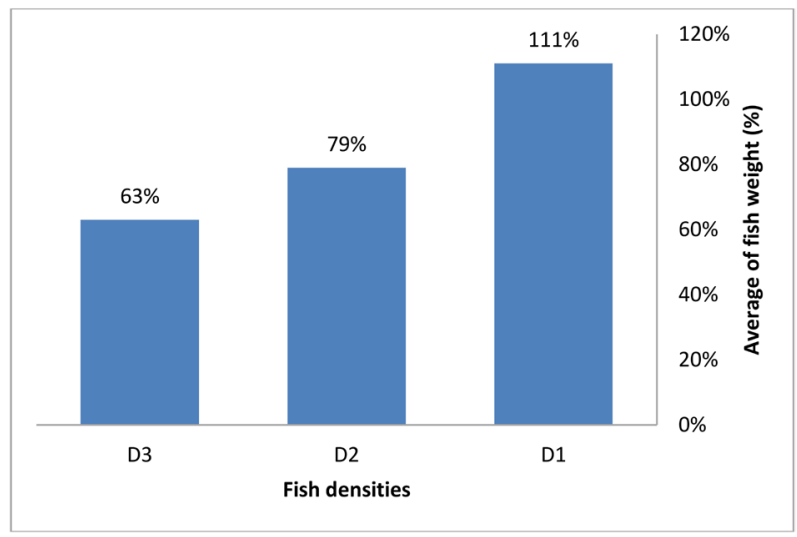

Figure 3. Growth rate (\%) of fish at three stocking densities.

Table 3. Growth parameters of Nile tilapia cultured for 10 weeks.

\begin{tabular}{cccc}
\hline & \multicolumn{3}{c}{ Stocking densities (fish/m $\left.\mathrm{m}^{3}\right)$} \\
\cline { 2 - 4 } Parameters & $\mathrm{D} 1$ & $\mathrm{D} 2$ & $\mathrm{D} 3$ \\
& $\mathbf{1 2 0 / \mathrm { m } ^ { 3 }}$ & $\mathbf{2 4 0 / \mathrm { m } ^ { 3 }}$ & $\mathbf{3 6 0 / \mathrm { m } ^ { 3 }}$ \\
\hline Initial weight (g) & $8.5 \pm 0.34$ & $8.7 \pm 0.36$ & $8.2 \pm 0.39$ \\
Final weight (g) & $17.9 \pm 0.40$ & $15.6 \pm 0.83$ & $13.4 \pm 0.84$ \\
Weight gain (g) & $9.4 \pm 0.31$ & $6.9 \pm 0.56$ & $5.2 \pm 0.68$ \\
Weight gain (\%) & $111 \pm 1.45$ & $79 \pm 1.87$ & $63 \pm 2.03$ \\
Daily growth rate (g) & $0.13 \pm 0.78$ & $0.10 \pm 0.83$ & $0.07 \pm 0.92$ \\
Total yield (g/m $\left.{ }^{3}\right)$ & $1128 \pm 2.12$ & $1656 \pm 2.08$ & $1872 \pm 1.94$ \\
Food conversion ratio (FCR) & $2.17 \pm 0.33$ & $2.79 \pm 0.28$ & $3.09 \pm 0.21$ \\
Survival rate \% & $62 \pm 0.81$ & $68 \pm 0.84$ & $62 \pm 0.81$ \\
\hline
\end{tabular}

The effect of temperature was clear-as the experiment was conducted mostly during the winter period. The growth rate of fish, which was slow in all treatments and this is primarily because since the fish are cold-blooded and are affected by the external environment as their metabolism rates decrease. Due to the low temperature, it is believed that the Nile tilapia fish which are warm-water fish - stop feeding when the water temperature drops below $18^{\circ} \mathrm{C}-20^{\circ} \mathrm{C}$.

The food conversion ratio (FCR) expresses the ability of fish to efficiently convert feed into body flesh and thus the feed efficiency of the fish [20]. FCR increased significantly with increasing fish stocking density. The lowest fish density was superior in terms of FCR value $2.17 \pm 0.33$, followed by the medium fish density with value $2.79 \pm 0.28$, while the FCR was $3.09 \pm 0.21$ in the high fish density Table 3. However, the relatively low FCR obtained in low-stock cages $\left(120 \mathrm{fish} / \mathrm{m}^{3}\right)$ suggests that the fish were to some extent able to extract more nutrients from the feed and then convert it into meat [21]. The FCR of low-density stocked fish is likely to indicate that low-density stocked fish may be more effective in converting the feed into meat than higher-stocked fish. The FCR in this study was similar to [22], which indicated that the feed conversion ratio increased with increasing stocking density in tilapia culture. 


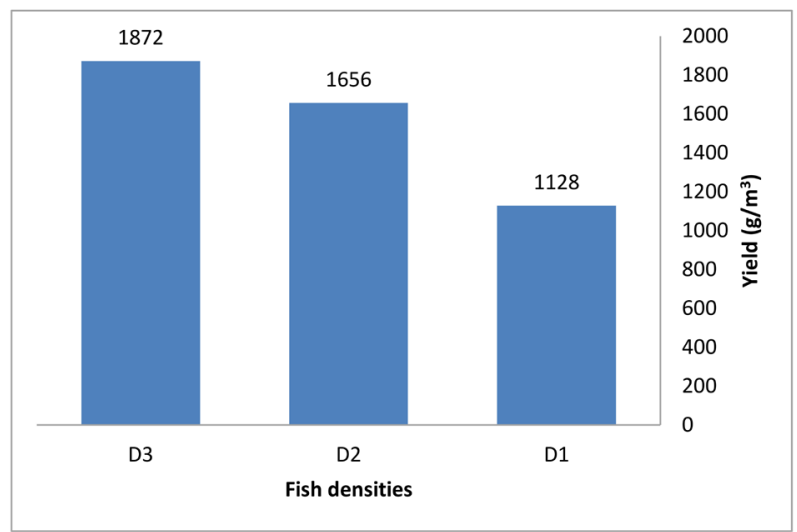

Figure 4. Total productions of fish (g) at three stocking densities.

On the other hand, a positive relationship between the stocking density and the Nile tilapia production was reported by [23]. These studies reported higher yields as stocking densities increased, as although the mean final fish weight and per capita growth rate at that density were the lowest of the three stocking densities. The highest total fish production was achieved in high density, which reached $1872 \pm 1.94 \mathrm{~g} / \mathrm{m}^{3}$, followed by the medium density, in which the total production was $1656 \pm 2.08 \mathrm{~g} / \mathrm{m}^{3}$. While the low density reached the lowest total production, reaching $1128 \pm 2.12 \mathrm{~g} / \mathrm{m}^{3}$ Figure 4 .

When comparing the three treatments according to partial budgeting in terms of return over food cost and taking into consideration the different parameters of growth performance over food cost, the medium density in this study (240 fish $/ \mathrm{m}^{3}$ ) might be the best and that could be recommended for this size of Nile tilapia.

\section{Conclusion}

The study found that the growth rate decreased as the fish density increased. However, total cage production increased as density increased, and the return on food cost increased as density increased. Based on the performance criteria of fish used in this study, it can be concluded that the medium density was the best $\left(240 \mathrm{fish} / \mathrm{m}^{3}\right)$. Growth was weak in the three treatments due to low temperature, as the study was conducted mostly during the winter period, which may raise some doubts about the viability of cage culture during this season.

\section{Conflicts of Interest}

The authors declare no conflicts of interest regarding the publication of this paper.

\section{References}

[1] Jayvardhan, V.B. (2019) Cage Culture of Oreochromis mossambicus (Tilapia) in Back Water of River Godavari, Nanded, Maharashtra India. MOJ Ecology \& Environmental Sciences, 4, 100-105. https://doi.org/10.15406/mojes.2019.04.00140 
[2] Bulcock, P. and McAndrew, K. (2001) Planning and Extension Guidelines for Small Scale Cage Aquaculture in Asia. Aquaculture News, 1-3.

[3] TWB (The World Bank) (2013) Fish to 2030. Prospects for Fisheries and Agricultures. World Bank Report Number 83177-GLB.

[4] Nandlal, S. and Pickering, T. (2004) Tilapia Fish Farming in Pacific Island Countries. Vol. 2. Tilapia Grow-Out of Ponds. Noumea, New Caledonia. Aquaculture Technical, 49.

[5] Chakraborty, S.B., Mazumdar, D., Chatterji, U. and Banerjee, S. (2011) Growth of Mixed-Sex and Monosex Nile tilapia in Different Culture Systems. Turkish Journal of Fish and Aquaculture Science, 11, 131-138.

[6] El-Sayed, A.F.M. (2006) Tilapia Culture. CAB International, Wallingford, 277. https://doi.org/10.1079/9780851990149.0000

[7] Sachin, O.K., Shanthanagouda, A.H. and Vijay, K.R.S. (2020) Influence of Stocking Density on Growth and Physiological Responses of Nile tilapia (GIFT Strain) in Cages. Journal of Experimental Zoology, 23, 731-735.

[8] Kapinga, I., Mlaponi, E. and Kasozi, N. (2014) Effect of Stocking Density on the Growth Performance of Sex Reversed Male Nile tilapia (Oreochromis niloticus) under Pond Conditions in Tanzania. World Journal of Fish and Marine Sciences, 6 , 156-161.

[9] Gullian-Klanian, M. and Arámburu-Adame, C. (2013) Performance of Nile tilapia Oreochromis niloticus Fingerlings in a Hyper-Intensive Recirculating Aquaculture System with Low Water Exchange. Latin American Journal of Aquatic Research, 41, 150-162. https://doi.org/10.3856/vol41-issue1-fulltext-12

[10] Rahman, M.M., Mondal, D.K., Amin, M.R. and Muktadir, M.G. (2016) Impact of Stocking Density on Growth and Production Performance of Monosex Tilapia (Oreochromis niloticus) in Ponds. Asian Journal of Medical and Biological Research, 2, 471-476. https://doi.org/10.3329/ajmbr.v2i3.30120

[11] Chakraborty, S. and Banerjee, S. (2010) Effect of Stocking Density on Monosex Nile tilapia Growth during Pond Culture in India. World Academy of Science, Engineering and Technology, 44, 1521-1534.

[12] Food and Agricultural Organization (FAO) (2014) The State of World Fisheries and Aquaculture: Opportunities and Challenges. Food and Agriculture Organization of the United Nation, Rome.

[13] Mensah, E.T.D. and Attipoe, F.K. (2013) Growth Parameters and Economics of Tilapia Cage Culture Using Two Commercial Fish Diets. International Journal of Development and Sustainability, 2, 825-837.

[14] Mohamed, A.A., Zaki, A.N., Alabssawy, A.M., Nour, M.B., Mahmoud, A.O., Dawood, S.A. and Mohamed, M.A. (2020) The Impact of Stocking Density and Dietary Carbon Sources on the Growth, Oxidative Status and Stress Markers of Nile tilapia (Oreochromis niloticus) Reared under Biofloc Conditions. Aquaculture Reports, 16, Article ID: 100282. http://www.elsevier.com/locate/aqrep https://doi.org/10.1016/j.aqrep.2020.100282

[15] Ronald, N., Gladys, B. and Gasper, E. (2014) The Effects of Stocking Density on the Growth and Survival of Nile tilapia (Oreochromis niloticus) Fry at Son Fish Farm, Uganda. Aquaculture Research and Development, 5, 1-7. https://doi.org/10.4172/2155-9546.1000222

[16] Garcia, F., Romera, D. and Gozi, K. (2013) Stocking Density of Nile tilapia in Cages Placed in a Hydroelectric Reservoir. Aquaculture, 410, 51-56. 
https://doi.org/10.1016/j.aquaculture.2013.06.010

[17] Costa, A.A.P., Roubach, R., Dallago, L.S.B., Bueno, W.G., McManus, C. and Bernal, M.E.F. (2017) Influence of Stocking Density on Growth Performance and Welfare of Juve Nile tilapia (Oreochromis niloticus) in Cages. Arquivo Brasileiro de Medicina Veterinária e Zootecnia, 69, 243-251. https://doi.org/10.1590/1678-4162-8939

[18] Sorphea, S., Lundh, T., Preston, T.R. and Borin, K. (2010) Effect of Stocking Densities and Feed Supplements on the Growth Performance of Tilapia (Oreochromis spp.) Raised in Ponds and in the Paddy Field. Livestock Research on Rural Development, 22, 227.

[19] Khatune-Jannat, M., Rahman, M.M., Bashar, M.A., Hasan, M.N., Ahamed, F. and Hossa, M.Y. (2012) Effects of Stocking Density on Survival, Growth and Production of Thai Climbing Perch (Anabas testudineus) under Fed Ponds. Sains Malaysiana, 41, 1205-1210.

[20] Ivan, A., Thaddeus, Z., Andrew, I., Howard, N.K., Norman, M., Steven, B., Mujibu, N., Sylvester, D.B., David, L.N. and Jackson, E. (2020) Effect of Stocking Density on Growth and Survival of Nile tilapia (Oreochromis niloticus, Linnaeus 1758) under Cage Culture in Lake Albert. Uganda International Journal of Fisheries and Aquaculture, 12, 26-35. https://doi.org/10.5897/IJFA2018.0671

[21] Alhassan, E.H., Kombat, E.O. and Karim, D. (2018) Growth Performance of the Nile tilapia, Oreochromis niloticus Cultured in Cages in Two Dams in the Bongo District of Ghana. West African Journal of Applied Ecology, 26, 11-21.

[22] Asase, A., Nunoo, F.K.E. and Attipoe, F.Y.K. (2016) Lake-Based Nursery Rearing of Nile tilapia (Oreochromis niloticus) Fingerlings in Nylon Hapas: Effects of Stocking Density on Growth, Survival and Profitability. Agricultural Science, 7, 660-669. https://doi.org/10.4236/as.2016.710062

[23] Gibtan, A., Getahun, A. and Mengistou, S. (2008) Effect of Stocking Density on the Growth Performance and Yield of Nile tilapia (Oreochromis niloticus L., 1758) in a Cage Culture System in Lake Kuriftu, Ethiopia. Aquaculture Research, 39, 1450-1460. https://doi.org/10.1111/j.1365-2109.2008.02021.x 